\title{
KRITÉRIA RECEPCE II. VATIKÁNSKÉHO KONCILU
}

PETER H ÜNER M A N N

\section{1. Úvod}

II. vatikánský koncil představuje v mnoha ohledech unikum mezi koncily: vzhledem k pouhému rozsahu svých dokumentů, k obsáhlosti svých témat, k adresátům - oslovováni jsou nejen katoličtí křestané, ale opakovaně všichni lidé -, k počtu zúčastněných koncilních otců a jejich reprezentativnosti rozdílných kontinentů a kultur, stejně jako vzhledem ke svým vytyčeným úkolům. Tento posledně zmiňovaný bod by měl být jmenován jako poslední a zároveň jako první. Vytyčený úkol koncilu je charakterizován čtyřmi hesly, které vzájemně velmi úzce souvisejí: první heslo: „aggiornamento“, druhé heslo: „nové letnice“, třetí heslo: „říkat víru novým způsobem“, čtvrté heslo: „pastorální koncil“. Toto v těchto heslech zmíněné zaměření koncilu bylo projednáváno $\mathrm{v}$ řadě vynikajících teologických pojednaní. Odvolávám se zde na ně, aniž bych tato hesla podrobněji rozváděl.

Způsob práce koncilu je vzhledem k předcházejícím koncilům rovněž mimořádný: vyznačuje se tím, že se znovu obrací k určujícím svědectvím víry v Písmu a tradici a sice $\mathrm{v}$ celé šíři tradice od prvotních svědectví a patristiky až po nejnovější papežská usnesení, jako třeba encykliky Pia XII. Jak má být tento mimořádný koncil recipován církví jako společenstvím věřících? Recepce znamená osvojení. Osvojení neznamená: přivlastnit si něco - to jde jen s penězi, s informacemi, s nějakými věcmi. Osvojení, aby se stalo vlastním, které utváří vlastní Já, funguje pouze tak, že se člověk vcítí do pozice druhého. Pozice druhého: Kde stojí koncil? Co opouští a jakým směrem se vydává? Těžká otázka. Ale pouze z tohoto východiska vyplývají kritéria pro recepci. 
Řečeno méně obrazně: Jaké jsou vnitřní a zároveň prokazatelné referenční body, které koncil určují? Vytyčený úkol koncilu je vlastně tak široký, že se přímo vnucuje otázka: Jak vznikl při tak vytyčeném úkolu a při tak velikém počtu účastníků z rozdílných kultur Korpus dokumentů, který se vyznačuje vysokou vnitřní konzistencí, silným propojením různých dokumentů ve vztahu k rozdílným teologickým tématům, který promlouvá k lidem z velmi různých kultur, ke křestanům a nekřestanům? Tyto referenční body, které určují stanovisko a budoucí cestu koncilu, tvoří odpověd' na otázku po kritériích pro osvojení, recepci koncilu. Lze tyto referenční body určit?

Tyto referenční body jsou dle mého čtyři jednoznačně pojmenovatelné body, které v sobě mají dvojitou strukturu: Jsou to dějinná, konkrétní místa, která jsou opouštěna a z kterých se koncil vydává na cestu za budoucností. Tato místa loučení a vydávání se na cestu jsou v dokumentech II. vatikánského koncilu jasně signalizována. Je tím jasně demonstrováno, co znamená „,aggiornamento“: „Aggiornamento" zahrnuje rozlišení toho, co bylo včera a toho, co vyžaduje dnešek. Loučení a vydávání se na cestu jsou dvě strany „aggiornamenta“. Jak lze určit tyto čtyři body loučení a vydávání se na cestu? Vyjmenuji v rychlém sledu tyto čtyři body, abych je posléze jednotlivě blíže charakterizoval. Závěrečná reflexe má sloužit k pojmenování a zdůvodnění metodických implikací. Z toho vyplývají otázky a důsledky pro recepci koncilu.

1. Koncil se loučí s 1500 lety církevního státnictví. Jasný signál nové cesty představuje Dignitatis humanae.

2. Koncil se loučí s tisíciletým rozkolem mezi východní a západní církví. Jasný signál nové cesty nacházíme jak v Orientalium ecclesiarum tak i v Unitatis redintegratio.

3. Koncil se loučí s 500 lety rozkolu církve na západě. Jasný signál nové cesty se nachází v Unitatis reintegratio.

4. Koncil se loučí s přibližně stoletým váháním církve na prahu moderny, reprezentované I. vatikánským koncilem. Signál nové cesty se nachází v Gaudium et spes.

Když budou v následující části charakterizovány čtyři jmenované body se svou dvojitou funkcí loučení se a vydávání se na novou cestu, vyzývá nás to k objasnění toho, jak je vzhledem k těmto bodům rozlučky a nového začátku opouštěna ta která specificky profilovaná 
dějinná podoba víry a církevního života a jak jsou prací II. vatikánského koncilu určovány obrysy nového profilu víry a životních forem církve. Bude tak patrné, jak dalece je vzhledem k těmto bodům plněn úkol církevních otců, ríkat víru nově a všem lidem, a tak spolupracovat na nových letnicich, to znamená na Duchem nesené najití nové polohy víry a života z víry. Zároveň je tak zodpovězena výzva, dostát s posláním spojené odpovědnosti, která je kladena na společenství věřících, na církev Ježíšem Kristem, jejím jediným pastýřem. Koncil se tak ukazuje jako pastorační koncil.

\section{K jednotlivým východiskům}

\subsection{Rozloučení se s tisícipètisty lety církevního státnictví - signál nové cesty: Dignitatis humanae}

Co znamená 1500 let církevního státnictví, od konstantinovského obratu až k postupnému ukončení církevního státnictví v rozmezí od vyhlášení americké nezávislosti až po konec Francova režimu? Toto církevní státnictví ve svých početných variantách nebylo pro víru a život církve jen něčím povrchním. Církevní státnictví utvářelo chápání víry a životních forem místních církví a církve jako takové.

Hlavni rysy opuštèné podoby víry - První hlavní rys: církevní státnictví způsobuje ze své podstaty základní identifikaci řádu víry a církve se státním nebo imperiálním veřejným právním řádem. Veřejné státní uspořádání je ale vždy spojeno s širokou paletou možných právních sankcí. Počínaje Nikají představují normy víry veřejné právní normy. Arius je se samozřejmostí poslán po koncilu do vyhnanství. Toto chápání norem víry jako právních norem, které jsou postižitelné trestem, se nadále udržuje v církevním hlásání víry v kanonickém právu. ${ }^{1}$ Tato vylučující a vymezující „definice“ víry, spojená s bezprostředními veřejnými, právními sankcemi se ukazuje v různorodých variantách: od administrativních opatření a jazykových obratů až po křížové výpravy, bojích proti jiným náboženstvím a s tím spojenými mocenskými nároky.

Pro tuto celou dobu ale zároveň platí, že teologie a učení církve nepodmíněně trvá na tom, že víru je možno přijmout pouze

1 Srv. BÖCKENFÖRDE, Ernst Wolfgang. Über die Autorität päpstlicher Lehrenzykliken am Beispiel der Äußerungen zur Religionsfreiheit. In: ThQ 186 (2006), s. 22-39. 
dobrovolně. Zde je založen vnitřní antagonismus, který si ustavičně razí cestu a projevuje se $\mathbf{v}$ jednotlivých významných křestanských postavách, přičemž formy takovéhoto protestu nabývají různých podob podle té které dějinné formy, kterou nabylo církevní státnictví v rozličných staletích. ${ }^{2}$

Druhý hlavní rys: Spojeno s církevním státnictvím a jeho vlivu na chápání víry a jednoduchá, nediferencovaná, prostá negace jiných náboženství resp. neortodoxních, odsouzených pojetí víry, je druhým hlavním rysem tohoto více než jedno tisíciletí trvajícího vztahu mezi státem a církví: Sakrální uspořádání společnosti a státu legitimuje v četných variantách samozřejmě veřejnou autoritu náboženským způsobem. Systém církevního státnictví, ve kterém žije křestanství, je určováno feudálním uspořádáním, které je křestansky legitimováno. To vede k tomu, že struktury úřadu samotné církve jsou charakterizovány a vykonávány po způsobu feudálního a stavovského uspořádání. To se od počátku této doby manifestuje $\mathrm{v}$ přidělování společenských privilegií biskupům, analogicky to pak platí pro kněze resp. faráře. Ukazuje se to ve vlastní soudní příslušnosti kleriků, a především v postavení Božího lidu, laiků.

Následky tohoto vývoje chápání úřadu jsou značné. Rozvíjí se v plné míre v oblasti středověké nauky o svátostech, ve které je integrováno pojetí úřadu. Laici, lid Boží, jsou viděni pouze jako adresáti darů milosti, které jsou jim skrze klerus poskytovány ve svátostech. Toto pojetí se udržuje až ke kněžským encyklikám papežů Piů a k textům připravovaným komisí kardinála Ottavianiho pro II. Vaticanum. ${ }^{3}$

Signál nové cesty - Shora byl již zmíněn dekret Dignitatis humanae jako signál nové cesty, na které se církev loučí s tou podobou víry a církevního života věřících, která byla utvářena tisíci pěti sty lety církevního státnictví. Dignitatis humanae proklamuje skrze návrat k evangeliu a rozumu náboženskou svobodu a tím zavrhuje formu církevního státnictví. Otcové koncilu se opírají o základní teologický princip, že člověk může přijmout a žít víru v Boha zásadně pouze svobodně. Ve vztahu k rozumu zakládají svou argumentaci na důstojnosti lidské osoby a na lidské svobodě. Tento rozumový princip byl

2 Srv. třeba Erasmovy kritické poznámky k válce proti Turkům In: Enchiridion militis Christiani.

3 Srv. pojednání autora k Presbyterium ordinis In: HThK Vat. II, 4, 342-357. 
zformulován a uznán až v moderně. Je to výsledek epochálního obratu v myšlení. ${ }^{4}$

První charakteristika nového profilu - V Nostra aetate, prohlášení o postoji církve k nekřestanským náboženstvím, se v bezprostředním kontrastu ukazuje, jaké následky byly pro teologii vyvolány rozloučením se s církevním státnictvím: „definice víry“ vykazující právnické kontury ve formě prosté negace ostatních náboženství je zavržena. Na místo jednoduché negace nastupuje diferencované přitakání, které implikuje pečlivé rozlišování toho, co je hodno souhlasu a diferencí, které je nutno odmítnout. Nostra aetate pouze ilustruje tuto novou zásadní volbu, kterou je nutno v tak umožněném dialogu podstatně prohloubit a rozvinout.

Velké konstituce II. vatikánského koncilu vykazují početné nové perpektivy, které vyplývají z opuštění pozice církevního státnictví:

-Dei verbum mluví ve stěžejním úryvku o „Zjevení Boha samého“ o tom, že Bůh sdělil sama sebe a že toto dění zahrnuje všechny epochy a období lidských dějin. ${ }^{5}$

- Lumen gentium paralelně k tomu tematizuje v první zásadní kapitole mystérium církve, které od počátku určuje dějiny lidstva. Jak spásu zprostředkovávající zjevení Boží tak i mystérium církve je možno díky opuštění státního církevnictví novým způsobem promyslet: odvolání prosté negace ostatních náboženství a zavedení diferencovaného přitakání k těmto náboženstvím umožnilo ptát se po přítomnosti Boží pravdy v náboženských tradicích lidstva. Vzhledem k sebeodkrytí Boha v Ježíši Kristu nemohou být deklarována pouze jako veličiny, které je nutno popírat. Zároveň se otevírá možnost, vidět mystérium církve v rozmanitých předběžných formách a znameních v náboženských a veřejných společenstvích lidstva. Skrze rozlišování duchů v dějinách lidstva se tak stane patrným dění vytváření Božího lidu na cestě k dokonalé humanitě, která se stane možnou skrze v Kristu zjevenou Boží milost. Je to lid Boží, který narůstá v dějinách lidstva a bojuje s moci zla, konečnosti a smrti, se zapletením se do násilných poměrů, do hříchu a viny. ${ }^{6}$

4 Srv. SIEBENROCK, Roman. Theologischer Kommentar zur Erklärung über die religiöse Freiheit Dignitatis humanae. In: HThK Vat. II, 4, s. 125-218.

5 Srv. Dei verbum $2-6$.

6 Srv. obzvláště Lumen gentium 16. 
Mimořádný význam má opuštění státního církevnictví pro koncepci církevní misie, jak je popsána v dekretu Ad gentes. Od dob pozdní antiky až do poloviny 20. století byla dynamika evangelizace úzce spojena a smíšena s politickými a hospodářskými zájmy říše a jejich následnických států. Evropské koloniální mocnosti jsou posledním příkladem toho, jak byla křestanská misie využita jako nástroj kulturně-sociální kolonizace, a církev z toho měla prospěch: Při mnoha př́íležitostech napomínala státníky, aby dostáli své povinnosti, podporovat misie. Patronántní práva španělské a portugalské koruny pocitovali papežové v některých záležitostech také jako svazující pouta. Jednalo se o ambivalentní vztah, vždyt́ dokonce i mimo své kolonie považovali evropské státy křestanské misie za činnosti, stojící pod jejich ochranou: např. v Číně až do dobytí Pekingu Mao Ce-tungem. ${ }^{7}$

Ad gentes tuto situaci ukončuje. Jediným základem misie a jejím modelem je sám Kristus. On znal srdce člověka, on přiváděl lidi „pravým lidským rozhovorem k božskému světlu“. 8 Tak mají žít jeho učedníci, naplněni jeho Duchem, spolu s ostatními lidmi, znát je a rozumět jim, sdílet s nimi svůj život, aby dokázali ocenit dary svých sousedů, pomoci jim, zasazovat se pro jejich společné dobro, aby mohlo vzniknout ovzduší důvěry a vzájemné důvěryhodnosti. Pouze na tomto základě se může uskutečňovat hlásání evangelia. ${ }^{9}$

Dalši charakteristiky nového profilu - S ukončením státního církevnictví je spojeno skoncování s feudálním, stavovským pojetí úřadu v církvi. Na jeho místo se dostává pozitivní charakteristika pojetí úřadu jako ministeria, jako služby na Božím lidu. Služebníci mají dopomáhat celému Božímu lidu, jednotlivci a společenstvím i církvi jako celku k tomu, aby se „snažili svobodně a spořádaně o stejný cíl, a tak dosáhli spásy“. K této službě obdrželi tito „ministři-služebníci“ své pravomoce. To znamená, že pravomoce mají svůj smysl, tedy i svůj daný rámec v Božím lidu, který je chápán jako svobobný, aktivní, posláním pověřěný subjekt. ${ }^{10}$

7 K vývoji misií a misijní myšlenky v 19./20. století srv. HÜNERMANN, Peter. In: HThK Vat. II, 4, 223-243.

8 Ad gentes 11.

9 Ad gentes 12.

10 Srv. Lumen gentium 18. Tento zde citovaný odstavec z 3. kapitoly dokumentu Lumen gentium o „Hierarchickém zřízení církve, zvláště episkopátu“ shrnuje jaksi zkratkovitě v tezích smysl a určení služby v církvi. Srv. HÜNERMANN, Peter. In: HThK Vat. II, 2, s. 406-408. 
Zásadní výpovědi dekretu o pastýřském úřadu biskupo̊ a dekret o službě a životě kněží potrzují toto nové profilování církevního úřadu. Biskupům je řečeno: „Při plnění svého otcovského a pastýřského úkolu at jsou biskupové uprostřed svých jako ti, kteří slouží, jako dobří pastýři, kteří znají své ovce a které také ovce znají, jako praví otcové, kteří vynikají duchem lásky a péče o všechny a jejichž autoritě, udělené Bohem, se všichni ochotně podřizují." 11 Rovněž je v církevní konstituci Lumen gentium zdůrazněna aktivní role členů církve, Božího lidu, který má vykonávat poslání Ježíše Krista. ${ }^{12}$

Dle Sacrosanctum concilium jsou liturgie a slavení svátostí primárně pojímána jako společné oslavy Božího lidu, v jejichž rámci účastníci přejímají své vlastní svébytné role. Liturgie není kult moci, nýbrž oslava milosti Boha, jeho „ponížení“ se v Kristu Ježíši kvůli nám.

Že skoncování se státním církevnictvím neznamená negaci, prosté popírání vztahu k veřejnému společenství, které se dnes odehrává nejen na státní, ale i na nadstátní organizační úrovni, to ukazují příslušná pojednání v Gaudium et spes. Zde je vytyčena nová perspektiva.

\subsection{Rozloučení se s tisíciletým rozkolem východní a západní církve - signál nové cesty: OR 14-18; UR 13-17}

Skoncování s rozštěpením na východní a západní církev, které trvalo tisíc let a které bylo udržováno z obou stran. Co to znamená?

11 Christus Dominus 16. Ohledně kněží srv. Presbyterium Ordinis 2 a 3 . Změněnému vymezení všeobecného úkolu těch, kteří byli v církvi pověřeni úřadem, odpovídá obměněné určení jejich „potestas“, jejich pravomocí. Pravomoc je nyní charakterizována jako pravomoc „pastýře“. Jedná se o pravomoc Krista, která určuje základ a míru moci „služebníků“, jejich pravomoc (potestas) je mocí pastorální, pravomoc pastýře. Toto terminologické pojetí a definování II. vatikánského koncilu přejímá CIC z roku 1983. Tento kodex říká jak o papeži tak o biskupech, že jsou ustanoveni k tomu, aby byli „pastores“. Srv. CIC (1983) can. 331; $333 \$ 2 ; 375 \$ 1$. Rozdíl, který je tímto vyjádřen, vyplývá z odpovídajících výroků CIC (1917), tak i ze všeobecných kanonistických ustanovení, která tvoří základ tohoto kodexu. Srv. Matthaeus Conte a Coronata, Institutiones iuris canonici, Marietti 1950, I, 321-325, N² 275-277. Potestas ordinaria, jak papežova, tak i biskupů, je zde definována jako „potestas publica regendi subditos in ordine ad finem societatis perfectae consequendum“. Tato potestas zahrnuje zásadně potestas legifera, iudicialis, administrativa, coactiva. To znamená, že všechny státní kompetence vykonávání moci jsou připisovány církevní autoritě. I když se vzhledem k církvi jedná o societas perfecta supernaturalis. Zajímavé je v této souvislosti zpracování této otázky v Confessio Augustana XXVIII, De potestate ecclesiastica.

12 Srv. obzvláště Lumen gentium 9-17; 33-38; dále Apostolicam actuositatem 1-4; UR 90-107; CD 16-18; GE 3.5.7; SC 7-13. 
Nejdříve: skoncování s tímto rozkolem znamená skoncování s přijetím tohoto schizmatu. Tím je myšleno obrácení se k druhému, ještě neukončené vyrovnání se se schizmatem, třebaže vzájemné vyhlášení schizmatu a zavržení bylo na závěr koncilu formálně zrušeno. Co vypovídá po obsahové a teologické stránce tisíciletá schizmatická koexistence?

První základní rys: na západě se vyvinula monokulturní církev, která pro svou monokulturní podobu vyžaduje univerzální platnost. Načrtněme nejdříve monokulturní podobu římskokatolické církve, která se vyvinula v tomto tisíciletí „klidné koexistence“.

Důležité momenty, ve kterých se manifestuje tato monokulturní jednota, jsou semknutost teologie v latinské církvi, založenou konkrétně na po staletí platné směrodatnosti Sentencí Petra Lombardského, které byly nahrazeny až v období protireformace Summou Tomáše Akvinského jako všude citovanou učebnicí. Dalším momentem je jednota církevního práva, která je založena na Dekretálech Gratiana zahrnující římské právnické prameny. Dále je nutno jmenovat ŕímsko-franckou formauliturgie se svým latinským jazykem, která je od karolinských dob pojímána jako panovnický kult Boha. Dalším momentem je jediný sakrální veřejný řád se svými církevními a světskými vazalskými strukturami. Přičemž je striktně rozlišováno mezi sférou spirituální a dočasnou. Sít klášterů a univerzit posilují tuto monokulturní podobu a tvoří podstatný prvek její infrastruktury.

Druhý základní rys: pluralitní jednotu prvního milénia nahrazuje úzká koncentrace a zaměření církve na centrální pozici Petrova následníka. Od přelomu 12. století až do dob protireformace učí mnozí teologové, že Ježíš vysvětil výhradně Petra na biskupa. Jako argument jsou uváděna dvě biblická místa: Mt 16 jako oznámení a J 21 jako vykonání tohoto vysvěcení. Teprve od Petra by ostatní apoštolové jaksi přijali biskupské svěcení. ${ }^{13}$ Následně se až do začátku II. vatikánského koncilu - Pius XII. o tom mluví v encyklice Mystici corporis - udržuje učení, že biskupové obdržují jurisdikci od papeže.

S odvoláním na Petra jako princeps Ecclesiae a princeps apostolorum je v těch několika málo setkáních mezi východní a západní

13 Tato otázka sehrála výraznou roli v diskusích během Tridentského koncilu. Srv. CT IX, 228, 22-229; III, 493, 14-494, 2. Zatímco skoro všichni kanonisté zastávají tento názor, existuje celá řada teologů, kteří zastávají pozici, odlišující se od té středověké a raně novověké. Tak např. Cajetan (Tractatus de Potestate Papae, c. 3), který učí, že ,apoštolové mimo Petra přijali (svěcení; poznámka autora) praeventivo modo od Krista“. Srv. OTT, Ludwig. Das Weihesakrament. In: HDG IV, 5, s. 125. 
církví tato monokulturní podoba pojetí zjevení, církve a teologie kladena jako bezpodmínečné měřítko: to se odráží ve sporu o francké filioque, o recepci II. Niceanea, v rozmíškách na Druhém lyonském koncilu o eschatologických záležitostech, na koncilu ve Ferraře a Florencii, kde se jednalo o unii s Řeky, Armény a jakobity stejně jako s Kopty. Na posledních zasedáních v Římě pak byly uzavřeny unie s dalšími Orientálci, se Syřany v Mezopotámii, chaldejci a maronity na Kypru: Orientálcům bylo uloženo, přijmout nauku o svátostech ve formě, která byla vypracována na západě.

Jaké perspektivy otevírá koncil tím, že se loučí s tímto rozkolem? Je nejprve dojemné číst na tomto pozadí výroky o katolických východních církví v Orientalium ecclesiarum: „Katolická církev má zájem, aby tradice každé partikulární církve neboli ritu zůstaly zachovány bez porušení, a zároveň chce, aby se způsob života těchto církví přizpůsobil různým dobovým a místním potřebám.“14

V Unitatis redintegratio je pozitivní význam tohoto rozloučení se $s$ rozkolem tematizován ještě výrazněji. Obzvláště patriarchálním církvím je výslovně potvrzeno, že zčásti odvozují svůj původ od samotných apoštolů a že mají „poklad, z kterého západní církev velmi mnoho čerpala v liturgii, v duchovní tradici a v právním řádu“. Dále se výslovně říká: „Avšak dědictví, předané od apoštolů, bylo přijato $\mathrm{v}$ různých podobách a různým způsobem, a proto už od začátku církve bylo tu a tam rozdílně vykládáno i vlivem nestejné mentality a životních podmínek.“ Následně jsou výslovně jmenovány rozdílné liturgické tradice, bohatost východního duchovního dědictví, rozdílnost církevních řádů, mravů a zvyků, která není zábranou „pro jednotu církve“, spíše církev obohacuje. ${ }^{15}$ Výslovně je jmenována rozdílnost teologických nauk a jim odpovídající utváření života. ${ }^{16}$

Prvni charakteristika nového profilu - V sobě rozmanitá jednota církve je v dokumentech II. Vaticana často zmiňována. Centrální je výrok, že církev se sestává v církvích a z církví. ${ }^{17}$ Církev může plnit své poslání pro lidi celého světa jen tehdy, když v sobě poskytne prostor pro pluralitu a právoplatnou rozmanitost. ${ }^{18}$

\footnotetext{
14 OE 2.

15 UR 16.

16 UR 17.

17 Srv. Lumen gentium 13; 23.

18 Srv. Gaudium et spes 92 .
} 
Druhá charakteristika nového profilu - Je důležité, že se v Unitatis redintegratio 18 výslovně prohlášuje, že „pro obnovení nebo udržení společenství a jednoty je nutné „neukládat žádné další břemeno kromě nutných věcí“ (Sk 15,28). Primát papeže je charakterizován jako „pastorales gubernium“, jako pastýřské vedení. Zároveň je těmto církvím řečeno, že všechny ,jsou si rovny důstojností, takže žádná nevyniká nad ostatní pro svůj ritus“, že všechny mají tytéž povinnosti a požívají tatáž práva.

Ve vztahu k patriarchům je výslovně potvrzena jejich samostatná jurisdikce a role papeže je opsána jako role arbitra, smírčího soudce, kdyby mělo dojít k rozporům mezi různými církvemi. Vzhledem k orientálním církvím je o papeži výslovně řečeno, že může zasahovat, v OE 4 je však také výslovně řečeno, že roli papeže je nutno vykonávat „in spiritu oecumenico, v ekumenickém duchu“, aby tak $\mathrm{v}$ daném případě vydával rozhodnutí, nařízení a směrnice. ${ }^{19} \mathrm{Na}$ konci pojednání o patriarchách je zdůrazněno, že tam, kde je nutno zřídit nové patriarcháty, je ,jejich ustavení vyhrazeno všeobecnému sněmu nebo římskému papeži“. Zde se zřetelně ukazuje nový profil služby Petrova nástupce.

\subsection{Rozloučení se s 500 lety odloučení katolíků a protestantů - signál nové cesty: Unitatis redintegratio 1-4}

Vzhledem ke skoncování s rozštěpením samotné západní církve platí rovněž, že toto skoncování nikterak neznamená zrušení rozštěpení, ale jistě se jedná o skoncování s lhostejným braním na vědomí daného odloučení a jeho následků. Výslovně je řečeno, že toto skoncování se zakládá na působení Ducha svatého jak v katolické církvi tak i v odloučených církvích. ${ }^{20}$ Co znamená toto skoncování po obsahové stránce?

Základni rysy opuštěné podoby víry - v souvislosti s rozštěpením, které vzešlo z reformačního úsilí pozdního středověku, se velmi rychle vytvořila forma víry a církevního života, která je označována pojmy „konfesionalizace“, „konfesní církve“. Co je tím míněno? Vzájemná naprostá negace vede k tomu, že se nemluví o křestanech, nýbrž pouze jen o katolících a protestantech. Teologické myšlení, propracování pojetí víry se jak na katolické, tak i na protestantské straně vyznačuje intenzívním systematizujícím úsilím. To znamená,

19 Ke vztahu k východním patriarchům srv. OE 7-11, obzvláště OE 9 .

20 Srv. UR 1 a UR 19nn. 
že se - spolu s vytlačením bohatství pojmů a nauk Písma svatého i tradice - prezentuje obraz pojetí víry stejně tak i obraz křestanského a církevního způsobu života, který se orientuje na protikladných bodech, které stojí v centru sporu o reformaci. Př́́kladem pro tento typ obsahového pojetí víry lze třeba jmenovat primární pohled na církev jako na „societas perfecta“, jak ji charakterizoval Bellarmin. Řeč o mystériu církve ustupuje oproti tomu do pozadí. Tématům jako učení o všeobecném kněžství se katolická strana vyhýbá. U pojetí úřadu stojí ve středu pozornosti několik málo aspektů, které jsou hodnoceny jako rozhodující: hlásání evangelia ustupuje oproti udělování svátostí, především mše, do pozadí. Příkladem takovéhoto konfesně zúženého pohledu na pojetí víry jsou neoscholastické dogmatické manuály, které se tradičních otázek 17. a 18. století chápou v rámci teologie, jež je tímto konfesionalizačním směrem již formována, a znovu je vyhrocují. Karl Rahner píše v prvním díle svých Schriften zur Theologie (1954): „V průměrných přednáškách dogmatiky by dnes bylo možné přednášet stejně tak dobře podle Billuarta nebo podle Wirceburgenses jako podle dnešní dogmatiky. Tam, kde se jedná o dogmatiku - to znamená ani dějiny dogmatu nebo jejich nuzné drobky ani haute vulgarisation -, se dnešní dogmatika neliší od svých předchůdkyň před 200 lety. “21 Rahner zároveň pozoruje, že v uplynulých staletích nebyly v teologii vytvořeny žádné nové termini technici, které by představovaly nové pojmové nástroje pro teologické myšlení. „Tam, kde věda ztratí svou pojmotvornou sílu, stává se ,sterilní (abych použil výraz z ,Humani generis“)."22 Tyto „sterilní“ manuály dogmatiky byly používány až do období na prahu II. Vaticana. Argumentace jsou vedeny v naprosto „pravoúhlé“ metodě od Písma k základním bodům tridentské obrany katolických, reformátory napadaných stanovisek. Přitom se tyto neoscholastické dogmatiky docela odlišují od na Tridentském koncilu ještě přítomné rozmanitosti teologických pozic. Na základě těchto forem konfesní systematizace byla možná naprostá negace evangelických křest́anů. Vymezující se stylizace v církevním životě vedla k rozdílnému kladení důrazu v různých zemích a náboženstvích, takže vznikají katolická resp. evangelická prostředí se silnými společenskými zvláštnostmi a výlučnostmi. Bylo by možné vyjmenovat množství takovýchto

21 RAHNER, Karl. Über den Versuch eines Aufrisses einer Dogmatik. In: Schriften zur Theologie sv. I, Einsiedeln - Zürich - Köln: Benzinger, 1954, s. 11.

22 Tamtéž, 12. 
odchylných bodů ve zbožnosti; dohromady vydávají svědectví o tom, že církev byla viděna vždy jako církev konfesní. Veřejno-společenské rozdělení katolíků a protestantů bylo téměř úplné. ${ }^{23}$

Signál nové cesty - O jaký signál se jedná, jenž vysílá II. vatikánský koncil, aby skoncoval s touto konfesionalizací a aby vytrhl z lpění na představě konfesní církve a mohl tak otevřít nové horizonty? Rozhodující poselství koncilu je formulováno v Unitatis redintegratio 3. Nejdříve se zde řeč o roztržkách a „dissensiones“.24 Mluví se o vině na takovýchto odloučeních, která vznikají „leckdy ne bez viny lidí z obou stran“. Pak je však učiněna podstatná výpověd” vzhledem k současné situaci: „Ti však, kdo se nyní rodí v takových společnostech a dosahují v nich víry v Krista, nemohou být viněni z hříchu odloučení a katolická církev k nim přistupuje s bratrskou úctou a láskou. Nebot́ ti, kdo věří v Krista a řádně přijali křest, jsou v určitém společenství s katolickou církví, i když ne dokonalém. Je pravda, že mezi nimi a katolickou církví jsou rozpory různého druhu jak v oblasti víry a někdy i kázně, tak ohledně struktury církve, takže plnému církevnímu společenství stojí v cestě nemalé překážky, někdy dosti vážné, o jejichž odstranění se snaží ekumenické hnutí. Nicméně však jsou vírou ve křtu ospravedlněni a přivtěleni ke Kristu, proto jim právem náleží čestné označení křestanů a synové katolické církve je oprávněně uznávají za bratry v Pánu.“25

Charakteristika nové podoby víry - Následně jsou v Unitatis redintegratio jmenovány četné momenty, které katolickou církev s odloučenými církvemi spojují. Odloučené církve a společnosti nejsou jako takové rozhodně „,bez významu a váhy v tajemství spásy. Nebot' Duch Kristův se nezdráhá používat jich jako prostředků spásy, jejichž účinnost se odvozuje z plnosti milosti a pravdy, která byla svěřena katolické církvi.“26 Tímto je princip konfesní církve a konfesionalizace pojetí víry ve shora charakterizovaném smyslu principiálně odmítnut.

Toto samozřejmě neznamená, že by víra už nemusela být vyznávána, ale vyznání víry znovu nabývá své plnosti a svého bohatství, protože vyznání víry a šíre s nimi danými pojetími víry jsou opět

23 Srv. GRAF, Friedrich Wilhelm. Konfessionskulturen. In: RGG4, IV, s. 1551n. Pojem „konfesní církev“ v zde předložené charakteristice „konfesionalizace“ nepřejímá jednoduše pozici a řečový úzus protestanské teologie. „Konfesní církev"vyjadřuje spíše typ pojetí víry.

24 Smyl tohoto pojmu je nutno brát v celé své šíři, od různosti názorů až po rozpor.

25 UR 3.

26 UR 3. 
jiným způsobem oceněny. V citované větě o působení Ducha, který používá odloučených církví a společností jako „prostředků spásy“, je zahrnuto i to, že zde existují a existovaly vývoje křestanského života a pojetí víry, od kterých se katoličtí křestané mohou učit.

Zároveň je - s distancí od konfesní negace - vyzván lid Boží, příslušníci katolické církve stejně jako ostatních církví a společností, aby se „horlivě účastnili ekumenického díla“. ${ }^{27}$ Signál je tím zřetelně dán: Jde o dialog, jde o to, poznat druhého v pravdě a tvořivě a vynalézavě pracovat na prohlubování pravdy a na jednotě, aby byly překonány rozkoly a nedorozumění. To neznamená, že se má jednoduše vzdát tradice rozdílných církví nebo že by vlastní identita již nehrála žádnou roli. Ale je zapotřebí, vyrovnat se se všemi těmito momenty, reflektovat je a prohloubit se zřetelem na společné prameny víry a se zřetelem na společnou budoucnost.

Zpřítomníme-li si základní rysy konfesionalizace a konceptu konfesních církví, je zřetelně vidět, že zde místo prosté a celkové negace, vzniklé konfesním zúžením systematizovaného pojetí víry, přichází diferencující přitákání. V tom se zde setkává skoncování a počátek s charakteristikou skoncování rozkolu na východní a západní církev, který jsme předtím popsali.

Oproti tridentské nauce o eucharistii, která byla zcela určována rozmíškami o kontroverzní body, se v pojednání o liturgii a slavení eucharistie jak v konstituci o liturgii tak i v pojednáních konstituce o církvi ukazuje podstatně integrační chápání mysteria paschale jako středu a vrcholu církevního života. Adekvátně tomuto chápání je opuštěno exkluzívní zaměření sakramentálního pojetí úřadu na obětní roli kněze a rozvinuto pojetí, které se odvozuje od třech křestanských základních služeb. Nauka o kněžském Božím lidu, kterému je svěřeno Kristovo poslání, je zeširoka rozvinuta. Zároveň je znovu navázáno na nauku o charismatech.

(Další důležitý styčný bod vyplývá společně s výše projednanými „referenčními body“: Zúžení, která tam bylo vykázána, se objevují vesměs také v oné zúžené podobě pojetí víry a způsobech církevního života, které jsme charakterizovali pojmy: konfese, konfesionalizace, konfesní církve. Tato zúžení se ovšem ukazují v tomto dějinném sledu znovu ve zvláštním profilu: Tento vývoj sahá od antického církevního státnictví až po vytváření uzavřených prostředí sociální

27 UR 4. 
povahy v 19. a v první polovině 20. století. Tomu odpovídá vytváření církevní struktury úřadu a služby až po úřednickou podobu sakrální autority presbyterů v poslední fázi konfesionalizace, např. skrze Pia X. Monokulturní forma katolické církve je znovu akcentována - od počátku středověku až po pokus Lva XIII., nastolit konfesně ovlivněnou modernu, která by byla založena na fundamentech tomistu.)

Hledáme-li v textech II. vatikánského koncilu signifikantní místa a nauky, které svědčí o rozbití konfesní podoby pojetí víry a církevního života, tak lze samozřejmě odkázat na řadu textů ve významných dokumentech. V Dei verbum je úplně jiným zpo̊sobem než v potridentské konfesní církvi vyzdvihován význam Písma a jeho četba pro všechny členy církve. ${ }^{28}$ Nový a Starý zákon je označen za duši teologie a její formy hlásání. ${ }^{29}$ Otcové se snaží přesněji určit vztah Písma a tradice. Převládající dominance tradice nad Písmem v katolické konfesní církvi se tak stává minulostí. Boží lid je viděn ve své důstojnosti jako knežský lid Boží. ${ }^{30}$ Lid Boží má bezprostřední účast na prorockém poslání Ježíše Krista. ${ }^{31}$ Služba v církvi je charakterizována především posláním hlásat evangelium, ${ }^{32}$ a tak dále.

Důležitý je nakonec ještě jiný postřeh. Tento postřeh bije do očí, položíme-li např. vedle sebe texty vypracované př́ípravnou komisí II. vatikánského koncilu a definitivně schválené dokumenty II. Vaticana. Nahrazení konfesního zúžení se ukazuje především ve způsobu a metodě vypracování textů: Převládá-li v přípravných dokumentech zcela jednoznačně pevná systematika a jí odpovídající abstraktní metodologie, jsou nyní do dokumentů v širokém rozsahu pojmuty texty z Písma, patristiky, ze středověku až po encykliky nedávno zemřelých papežů, které jsou zároveň ve své vlastní osobitosti a svém profilu respektovány. To se ukazuje především na způsobu, kterým jednotlivé komise zdůvodňují nebo odmítají převzetí návrhů na změnu, jak vysvětlují či ospravedlňují jednotlivá slova. Koncilní otcové se již nepohybují v „pravoúhle“ daných kolejích konfesní víry a konfesního chápání církve.

\footnotetext{
28 Srv. DV $21 \mathrm{nn}$.

29 DV 24.

30 LG 10.

31 LG 11-13.

32 LG 20.
} 


\subsection{Skoncování se sto lety prodlévání na prahu moderny - signál nové cesty: Gaudium et spes}

Skoro sto let čítá období, které od sebe dělí I. a II. Vaticanum. Je zde ohlášena rozlučka $\mathrm{s}$ I. Vaticanem?

I. vatikánský koncil schválil dvě konstituce: konstituci o katolické víře Dei Filius a dogmatickou konstituci o církvi Kristově Pastor aeternus.

Základni rysy se skoncovanou podobou víry - Konstituce o víře pojednává o nanejvýš dramatické otázce, která je kladena modernou a rozvojem moderní vědy: Není víra zásadně oblastí, která by se měla podřídit vědě jako nejvyšší instanci a autoritě v oblasti poznání? Koncilní otcové na tuto vyzývavou otázku odpověděli: Víra se opírá o Boží zjevení, kterým zjevil Bủh „lidskému pokolení nadpřirozeným způsobem sám sebe a věčná rozhodnutí své vůle“.33 Zároveň existují - vedle působení Ducha - racionální důvody, které mluví pro věrohodnost zjevení. Od zjevení jako základu víry je nutno rozlišovat rozum a jeho řád: „Také totoho se držela a drží katolická církev v nepřetržité svornosti, že existuje dvojí řád poznání, který je rozdílný nejen v principu, ale i v předmětu [poznání], a sice v principu, nebot' v jednom [řádu] poznáváme přirozeným rozumem, v druhém božskou vírou; v předmětu ale [se liší], poněvadž nám jsou kromě toho, k čemu je schopen dojít přirozený rozum, předkládána v Bohu skrytá tajemství, která, kdyby je nám Bủh nezjevil, by nám nebylo možno poznat.“34 S tímto rozlišením se koncilní otcové vrací k učení Tomáše Akvinského. Otcové potvrzují svébytnost a autonomii věd a zdůrazňují, že víra a rozumové poznání si nemohou protiřečit, protože obě mohutnosti mají svůj původ ve stejném Bohu, v onom Bohu, který je stvořitelem a dovršitelem lidského pokolení.

Proč se v nadpisu hovoří o prodlévání na prahu moderny? Protože tato z tradice převzatá odpověd' může být čtena dvojím způsobem: Zaprvé jako striktní vymezení obsahů zjevení, resp. víry a oblasti vědy. S oba řády poznání, víry a rozumu, je pak zacházeno jako se smyslovým poznáním a racionálním poznáním: Obě mohutnosti jsou rozdílné, a to, co je uchopeno smysly se odlišuje od předmětů rozumového poznání. Rozum nečichá, čichovým orgánem nelze postihnout logiku. De facto bylo vyjádření I. vatikánského koncilu chápáno zcela tímto způsobem, patrnými doklady toho jsou např. vysvětlení

$\overline{33}$ DH 3004.

34 DH 3015. 
biblické komise. Židé a křestané vždy mluvili o Mojžíši jako o autorovi prvních pět knih Bible, pročež historická věda, kritická filologie zde nemůže přicházet s pochybnostmi a předkládat protiargumenty. Teprve ve velmi pomalém procesu otevřel Pius XII. s encyklikou Divino afflante opatrně dveře k jinému pohledu, teprve s pojednáními v Dei verbum je ve vztahu k Bibli zrušena tato dvojkolejnost, teprve v Gaudium et spes je tato dvojkolejnost v zasádní podobě ve vztahu ke všem oblastem vědy zrušena, ${ }^{35}$ teprve encyklika Fides et ratio Jana Pavla II. vyzdvihuje druhý - mimo ten shora uvedený princip, který určuje vztah víry a myšlení v tradici od Augustina až po vrcholný středověk - rovněž u Tomáše Akvinského: že se totiž víra a myšlení vzájemně prolínají. Tento princip zformuloval Augustinus: „Věřit neznamení nic jiného, než souhlasně myslet (cogitare cum affirmatione). [...] Každý, kdo věří, myslí, když věří, myslí, a když myslí, věří. [...] Když víra není [pro]myšlena, není nic.“376

Důsledek, který z toho vyplývá: Věroučnou konstituci I. Vaticana je možno číst jako konec a vyvrcholení procesu konfesionalizace víry a vytváření konfesních církví, poněvadž je zde zcela zásadním způsobem prezentována vůči moderní vědě zcela odloučená oblast víry a pojetí víry. ${ }^{37} \mathrm{~V}$ tomto smyslu reprezentuje I. Vaticanum se svou věroučkou konstitucí prodlévání na prahu moderny: Moderna byla sice vzata na zřetel, ale zcela pod zorným úhlem protestu, konfesionalizace a naprosté negace moderny. Potud je tedy nutné, rozloučit se s I. Vaticanem.

Zároveň je tento výrok ve věroučné konstituci I. Vaticana nutno brát jako bod obratu, jako počátek nové cesty, pokud je tomuto výroku komplementárně přidružen druhý princip chápání víry, které vychází ze vzájemného prolínání žití víry a myšlení a tak víru a myšlení spojuje při vší odlišnosti v těsný vzájemný vztah. A toto nastalo na II. vatikánském koncilu.

35 Budiž připomenuto, že se Pius XI. v Humani generis dožaduje monogenismu, tj. původu celého lidského pokolení od jednoho lidského páru kvůli dogmatu dědičného hříchu. Srv. DH 3897.

36 AUGUSTINUS. De praedestinatione sanctorum 2,5; PL 44, 963.

37 Tento pohled byl při př́ípravě I. Vaticana pohledem zcela vůdčím. V připraveném schématu církevní konstituce, která na samotném koncilu nemohla být projednána, se vzhledem k vývoji po Tridentském koncilu říká: „Poté, co bylo opuštěno a vzdáno křestanské náboženství, sklouzlo nakonec myšlení mnoha lidí do propasti panteismu, materialismu a ateismu. Již to došlo tak daleko, že popírají samotnou rozumovou přirozenost a každou normu dobra a spravedlnosti a tak se snaží zničit základy lidské společnosti“ (COD 3, 804n.). 
Druhá konstituce I. Vaticana, ve které jde o primát papeže a o nauku jeho neomylného magisteria, vykazuje stejnou „vnitřní strukturu“ jako konstituce věroučná.

Oproti zdůvodnění veřejné autority ze sebeurčení lidí, národa státu odůvodňuje I. vatikánský koncil církevní autoritu zjevením. Začíná u nejvyšší autority v církvi, u Petra a jeho následníků, a definuje primát jurisdikce. Je příznačné, že otázka, jak má být tento primát jurisdikce a magestieria vykonáván, není tematizována. V teologickém úvodu k těmto výrokům o primátu a magisteriu jsou sice takovéto momenty naznačeny, ale nejsou blíže reflektovány a už vủbec nebyly přejaty do odpovídajících definičních formulací a do kánonů. 38 Že i tento druhý dokument lze tedy interpretovat ve smyslu striktně hierarchizovaného, model konfesní církve završujícího výkladu, a de facto i tak interpretován byl, je nasnadě. Že nauka o papežském primátu a magistériu může být i novým výchozím bodem, ukazuje II. vatikánský koncil, který mluví ve svých pojednáních o kolegialitě. Koncil zdůrazňuje, že biskupům skrze jejich svěcení přísluší také řádná jurisdikce, to znamená zplnomocnění vést v plné šíri této pravomoci v jejich příslušných místních církvích. Koncil mluví o tom, že patriarchové mají ve svých příslušných církvích nejvyšší i metropolity zahrnující zákonodárnou funkci. Role papeže je charakterizována jako role „smírčího soudce“, když někdy dojde mezi jednotlivými patriarchálními církvemi ke sporu. Koncil mluví o „pastorale gubernium“, které papež ve vztahu k rozdílným východním církvím vykonává. Toto všechno poukazuje na to, jak má být nyní nově určena Petrova služba papeže v novém, hlubším pohledu církve. Také zde bychom mohli odkázat na Jana Pavla II., který ve své ekumenické encyklice Ut unum sint výslovně vyzval odloučené církve, aby mu pomohly, opsat službu Petrovu tak, aby se vůbec mohl věnovat svému úkolu, starat se o jednotu křestanů. V této podobě se také zde vzhledem k I. Vaticanu jedná o skoncování a počátek nové cesty, nebot' je výslovně kladena otázka po způsobu ,jak“ vykonávat primát a jsou otevřeny nové perspektivy, jakým směrem se mají věci ubírat. To samé platí o výrocích o neomylném magisteriu římského biskupa. Při diskusi na I. vatikánském koncilu bylo mluvčím deputace pro víru, biskupem Gasserem, výslovně poukázáno na to, že se u infalibility Romani Pontificis nejedná o absolutní neomylnost - tato přísluší pou-

38 Srv. DH 3061; 3069, kde je episkopát a zapojení episkopátu do vykonávání učitelského úřadu papeže alespoň mimochodem zmíněn. 
ze Bohu -, nýbrž o neomylnost analogickou: „Absolutní neomylnost náleží pouze Bohu, první a bytostné pravdě, která nikdy neklame ani nemůže být nějak oklamána. Protože každá jiná neomylnost je vyslovena za určitým účelem, má hranice a podmínky, dle kterých má být posouzeno, zda se o neomylnost jedná.“79

Bližší charakteristiku této „neomylnosti“, která je přisouzena definitivním věroučným rozhodnutím římského biskupa, I. Vaticanum nepodává.

II. Vaticanum oproti tomu výslovně jmenuje rozdílné loci theologici, instance resp. oblasti, které reprezentují víru: smysl pro víru Božího lidu, Písmo, koncily, církevní otcové, shodná nauka teologů, na kterou je papež ve svých věroučných rozhodnutích odkázaný. Papežovi se nedostává nového zjevení. Zde se jasně manifestují podmínky, na jejichž dodržení a na věcném zacházení s nimi závisí kvalita papežských výroků a rozhodnutí, i těch, které činí z funkce nejvyšší instance.

Druhý moment vyplývá ze vztahu k užívání slova „neomylný“. Toto slovo „neomylný“ označuje pravdu, která nikdy neklame ani nemůže být nějak oklamána. Analytická filosofie prokázala ve vší jednoznačnosti, že neomylnost implikuje úplný soulad subjektivního výkonu myšlení a obsahu myšlení, toho „co“ myslíme. Toto však leží zcela mimo jakoukoliv možnost lidského myšlení. Jedná se o naprosto mezní případ, který předpokládá tvůrčí myšlení, to znamená - teologicky řečeno - Boha jako prima veritas, od které pochází všechno manifestující se vznikání a pravdivost bytí.

To ale znamená, že slovo „neomylný“ může být v oblasti stvoření přisouzeno pouze víře jako takové, protože víra jako obiectum formale věří všechny obsahové výroky pouze tehdy, když pocházejí od Boha jako prima veritas a znovu k němu jako prima veritas přivádějí. V tomto smyslu je víra - jak to už vyjádřil Tomáš Akvinský - neomylná. ${ }^{40}$

Slavnostní věroučná rozhodnutí papeže jsou sama v sobě za daných podmínek důvěryhodná. K těmto rozhodnutím jako svědectvím víry je možno se správně vztahovat a správně chápat pouze tehdy, když je

39 Mansi 52, 1214 A; srv. k tomu POTTMEYER, Hermann Joseph. Die Rolle des Papsttums im dritten Jahrtausend (QD 179). Freiburg - Basel - Wien: Herder, 1999, s. 81-90.

40 Srv. HÜNERMANN, Peter. Dogmatische Prinzipienlehre. Münster: Aschendorf, 2003, s. 252-273. 
věřící ve víře vykonávají. Pak ale platí, že věřící vykazují - vzhledem k Písmu v menší míře - určitý stupeň neomylnosti, který vylučuje neopravitelné fundamentální omyly, které by znemožnily zásadní setrvávání v pravdě Ježíše Krista. Naproti tomu je II. vatikánským koncilem výslovně uznáno, že i v Písmu se mohou nacházet omyly a jednostrannosti. ${ }^{41}$

V II. vatikánském koncilu se tudíž nejedná pouze o překonání zúžené ideje konfesní církve, nýbrž podstatně o překročení onoho prahu a onoho prodlévání na prahu moderny, které je reprezentováno I. Vaticanem. Toto překročení se jasně rýsuje jak v Lumen gentium tak i v Dei verbum. V plné šíří signalizuje toto překročení ale Gaudium et spes.

Hned v předmluvě k Gaudium et spes se hovoří o spojení a vnitřní jednotě církve jako společenství věřících s „radostí a nadějí, smutkem a úzkostí lidí naší doby, zvláště chudých a všech, kteří nějak trpi““.

V první části pojednává Gaudium et spes o důstojnosti osoby člověka v kontextu dnešní situace, o společenství lidí a jejich činností, o jejich tvůrčím úsilí. Je ukázáno, jak se toto základní téma moderní antropologie ve světle víry vyjasňuje. Víra přispívá k jejímu porozumění a k odpovídající životní orientaci. Gaudium et spes mluví o vzájemném dialogu, který spolu vedou společnost a hospodářský sektor na jedné straně a církev na straně druhé. ${ }^{42}$ Obsah druhé části Gaudium et spes - manželství a rodina, kultura, hospodářsko-společenský život, život politického společenství, mír a společenství národů - pojednává o problémech, ohroženích a o příslušném pohledu, který vyplývá z víry. Příznačné je také zde vzájemné prolínání rovin, otevřenost rozlišujícího, diferencujícího dialogu. Tyto signály a náznaky se zásadně odlišují od konceptu Lva XIII., od pohledu na vztah mezi církví a modernou Pia X. nebo od vytvoření katolické sociální nauky, která byla pod Piem XI. a Piem XII. dále koncipována jako čistě filosofická nauka, která se církve samotné, jejího života a jejího pojetí víry netýká.

Se zřetelem ke změnám, které se projevují ve vývoji člověka v posledních desetiletích, vzhledem ke globalizaci všech

\footnotetext{
41 Srv. DV 11-13: O božské inspiraci a výkladu Písma svatého. Rovněž DV 15, kde je výslovně řečeno, že knihy Bible obsahují „též věci nedokonalé a dočasné“. Doslovná inspirace a absolutní bezchybnost knih Starého a Nového zákona jsou koncilem výslovně odmítnuty.

42 Srv. GS 40-45.
} 
společenských a hospodářských vztahů, k obrovské expanzi lidských možností zasahovat a přetvářet primární přírodu, jsou zde nastaveny nutné předpoklady a je zde ukázáno, jak se církev má a musí postavit k rozvíjející se moderně.

V tomto vydávání se na novou cestu se avšak vzhledem k novému návratu k evangeliu zároveň ukazuje, kolik historické viny vplynulo do forem té které dějinné podoby pojetí víry a do forem pohledu na církev a podob církve. Potud mají skoncování a počátek, tak jak byly proklamovány II. vatikánským koncilem, charakter obrácení, které musí být doprovázeno vyznáním viny. Zároveň jsou tyto nové počátky důkazy Ducha a síly, která působí ve společenství věřících skrze evangelium.

\section{Tři poznámky jako doslov}

\subsection{K formální charakteristice zde předložených kritérií recepce II. vatikánského koncilu}

Recepce II. vatikánského koncilu se odehrává na rozličných úrovních a v tisíci procesech: $\mathrm{v}$ modlitbě jednotlivého věřícího, $\mathrm{v}$ administrativních rozhodnutích nějaké diecéze, ve vatikánských vyhlášeních a církevně-právnických směrnicích, v oblasti vytváření veřejného mínění, v symbolickém gestu Jana Pavla II. u jeruzalémské Zdi nářků. Tato recepce je nesmírně komplexní proces veřejné, církevní a společenské dimenze. Přitom samozřejmě existují rozdílné názory a mínění těch, kteří se na této recepci podílejí. Kritéria musí být tedy formulována s velkou společenskou, církevní jasností a výstižností, jinak nemohou poskytovat obecnou orientaci. Musí odpovídat - protože se jedná o pravdu a přiměřenost těchto kritérií - svou vnitřní dimenzí komplexitě věcných otázek projednávaných v koncilních dokumentech. Kritéria musí vyvěrat ze samotných textů a pragmatiky samotného koncilu. Musí být vykázána v samotném koncilu, v koncilových textech a musí reprezentovat pragmatiku koncilu, jelikož smysl výroků a nauk se odvíjí vždy jen od příslušné pragmatiky.

Proto byla vybrána zde představená cesta ptaní se po rozloučeních a počátcích nové dějinné podoby víry a církve, provedené samotným koncilem. V této otázce jsou zahrnuty i ty příslušné body - toto tvoří jejich vnitřní, plurální dimenzovanost - , to znamená instance svědectví, o kterých pojednává dogmatická nauka o principech, a sice loci proprii a loci alieni, které se musí brát teologicky v úvahu při 
definování výkladu víry a při řešení kontroverzních otázek. 43 Tyto rozdílné instance zde byly představeny ve svých konkrétních, jaksi příslušných komprimovaných podobách tím, že jsme se bezprostředně ptali po dějinných podobách pojetí víry a koncepcí církve. Tím jsme chtěli učinit zadost snadnému zacházení s matérií a pregnanci, která je požadována od kritérií recepce.

\section{$3.2 O$ co $v$ práci s tèmito kritérii jde?}

Jako každý člověk a jako každá dějinná, sociální veličina nebo společenství získává též společenství věřících, církev, svou dějinnou identitu vždy ze světa a ve světě, ve kterém se nachází: K tomu patří samozřejmě její původ od Ježíše Krista a nadějeplné zaměření na eschatologickou budoucnost, nebeský Jeruzalém. K tomu ale patří rovněž konkrétní vytváření této identity v daných dějinách, $\mathrm{v}$ jejích epochálních proměnách a globálních situacích. Pouze v této kon-kreci je přítomna víra ve zjevujícího se Boha, ve vykoupení skrze Ježíše Krista v dějinách. V recepci se tudíž jedná o nabytí křestanské identity jak jedinců, rodin tak i církve a církví a křestanských společenství.

Když vycházíme z dějinných instancí pojetí víry a církve, z jejich skoncováním a s tím spojeným počátkem v dění koncilu, ukazuje se přitom „konstitucionální charakter dokumentů II. vatikánského koncilu““44 Je zřejmé, jakou dějinnou podobu nebo stav pojetí víry a církve má církev za sebou a jakým smèrem se vydává na cestu. Mluvit o „konstitucionálním charakteru“ těchto dokumentů, proto ještě neznamená, interpretovat koncil právně. ${ }^{45}$

\subsection{K současné krizi církve}

Možná to zní troufale, zakončit tento teologický náčrt o kritériích recepce II. vatikánského koncilu s poznámkou k současné krizi katolické církve. Současná krize se řadí do oné řady krizí, která postihla církev od konce 18. století, napoleonských zmatků, od základního výnosu říšské deputace. Vnějšími příznaky byly bezpochybně

43 Srv. k tomu: HÜNERMANN, Peter. Dogmatische Prinzipienlehre. Münster: Aschendorf, 2003, s. 193-275.

44 Srv. HÜNERMANN, Peter. Der Text: Werden - Gestalt - Bedeutung. Eine hermeneutische Reflexion, In: HThK Vat. II, 5, 1-95; týž, Der übersehene „Text“. Zur Hermeneutik des II. Vatikanischen Konzils, In: Concilium 41 (2005), s. 434-450.

45 Srv. kritické námitky od Christopha Theobalda proti zde předložené tezi, In: La réception du Concile Vatican II, Paris 2009, Bd. 1, s. 435-436. 
sekularizace duchovních knížectví, zrušení církevního státu, rozklad katolického milieu. Vnitřní dosah krizí, který se v těchto vnějších symptomech pouze náznakem manifestuje, sahá hlouběji a je dalekosáhlejší, než bylo dosud asi povědomé a než bylo realizováno. Celkově jde o zde naznačené rozlučky, které jsou zatěžko nejen proto, že podoby víry a církevního života, s kterými bylo skoncováno, představují důvěrně známé životní světy, které však již prostě pozbyly platnosti. Tato skoncování jsou také proto obtížná, protože obrysy nové podoby víry a církevního života předpokládají nové podrobné promyšlení víry a sociálních forem společenství církve, které se těžko vypracovávají. Koncil poskytuje a předkládá vždy jen perspektivy. Přitom je nutno zohlednit, že krok od Newtonova obrazu světa k obrazu světa moderní fyziky není větší než krok od pojetí víry a církve Roberta Bellarmina k současnému. Přitom nepomůže žádné lpění na předmoderně a jejích dějinných podobách víry a církevního života, nýbrž pouze vytrvale vykonávání, krok za krokem prováděné skoncování a nový počátek v síle Ducha.

\section{RESUMÉ \\ PETER HÜNERMANN \\ Criteria for the Reception of the Vatican Council II}

Criteria for the reception of the Second Vatican Council have to be manageable for broad segments of the population and not just for scholars. The reception plays a role on many different levels and is being effected by very different protagonists. For this reason four documents are singled out here, each of which bids farewell to historical forms of faith and church life and initiates the emergence of new forms:

1. With the Declaration on Religious Freedom leave is taken from the statechurch system which existed for 1500 years. What new form is emerging?

2. With the Decree on the Catholic Churches of the Eastern Rite and Unitatis Redintegratio the 1000-year split into an Eastern and a Western Church is rejected and the departure from a mono-cultural understanding of the faith and of the church is announced.

3. In the Decree of Ecumenism the emergence from a denominationalecclesiastial system is achieved.

4. The Pastoral Constitution on the Church in the Modern World represents the overcoming of the hesitation on the thresholdk of the modern age, a characteristic of the First Vatican Council which lasted about 100 years. 
In the closing reflections the texts of the Second Vatican Council are recognized as constitutional texts. They mark cornestones of a 'constitution' of the church in the modern age. The current crisis is one moment in the major transformation process that is under way.

Key words

Vatican Council II, Dei Verbum, Dignitatis Humanae, Nostra Aetate, Unitatis Redintegratio 

VARIA 
